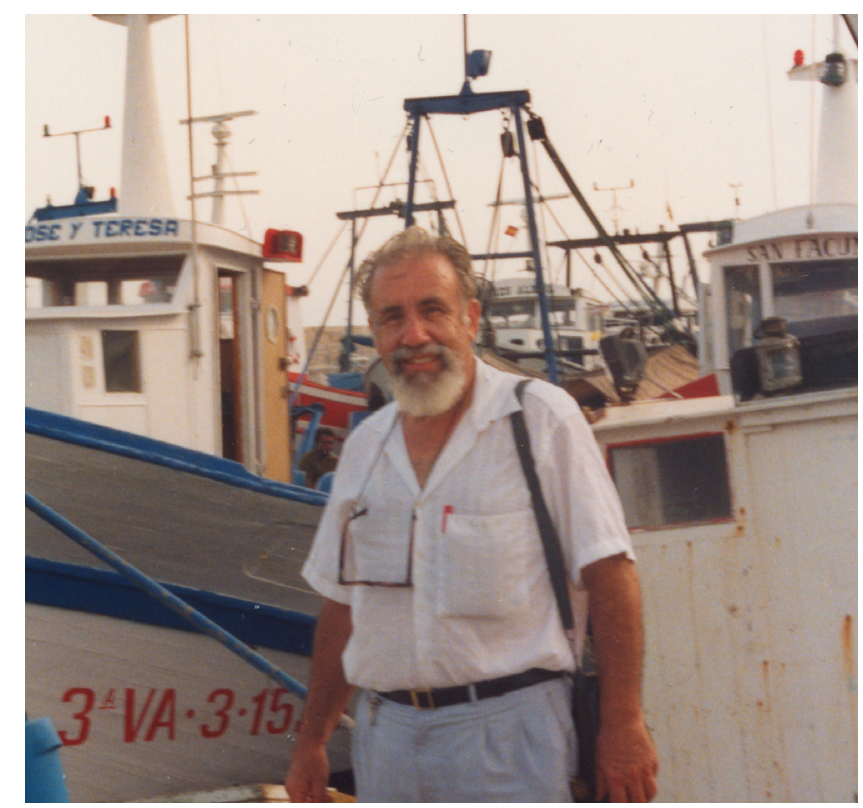

\title{
Pere Arté i Gratacós (1924-2009)
}

Pere Arté i Gratacós was born in Figueres on 22 November 1924 and graduated in Natural Sciences in Barcelona in 1950. He began to work as an intern before he graduated, when the Spanish National Research Council (CSIC) created the Marine Biology Section in 1949. He also attended the course «Introduction to Fisheries Research», which was given in Barcelona and Blanes. He already showed an interest in fish, and in the same year he published a study on the fishes of the Blanes coast. Between 1950 and 1955 he worked as a scientific collaborator of the CSIC in Vigo. During this period he collaborated with Buenaventura Andreu on studies of flat oyster cultivation, at a time when the situation of the natural banks of this species was a cause for concern. In 1953 Arté and Andreu visited oyster parks and laboratories on the French Atlantic coast (Arcachon, Tremblade and Marennnes), gathering information to be used in later studies that he carried out on larval attachment, growth and mortality of oysters in the Galician rias. His stay in Vigo was also very important from the personal point of view. It was there that he met his wife Montserrat Escatllar, who was working as a laboratory assistant and from then on followed him throughout his life.

On returning to Vigo, Arté worked for two years (1956 and 1957) at the Blanes Laboratory of the
Fisheries Research Institute (IIP). In the spring of 1958 he joined the Barcelona Laboratory when GarcÍa del Cid, director of the IIP, asked him to design and build the future Aquarium of the IIP. From then on, Arté put all his efforts into this task, undertaking the design, the water supply and the decoration of the tanks. With the help of Baldomero Carles and José Grau, the sailors who accompanied him on his «fishing expeditions», he began to populate the aquarium. He also visited the aquariums of Monaco, Lisbon and Oporto to exchange experiences. Finally, with a complete sample of the Mediterranean marine fauna, the aquarium was inaugurated in June 1963 and Arté's efforts were rewarded with the Civil Order of Alfonso X the Wise. Under Arte's direction, and with the collaboration of Enric Morales, the aquarium made a great contribution to spreading knowledge of marine life among schoolchildren and the general public. He also contributed to research through studies and doctoral theses based on maintaining fish and invertebrates in controlled conditions.

Arté's work was a good model of applied science because his scientific and technical knowledge allowed him to carry out many projects to solve the problem of sea water supply in coastal marine laboratories and other aquariums. He directed technical 
projects for the construction of seafood farms in Barcelona, Tarragona and Mallorca. He also worked on eel-breeding farms and was involved in the design of mollusc purification systems. He published several papers on subjects such as water oxygenation systems for aquariums, maintenance of animals in captivity and aquariology. In 1965, together with F. Lozano and O. Rodríguez, they published Nomenclatura oficial española de los animales marinos de interés pesquero (Official Spanish Nomenclature of Marine Animals of Interest to Fisheries), of which a second edition was published in 1972. In this book they proposed an official nomenclature to unify the regional ones for commercial fish, crustaceans and molluscs. Thanks, to Arté, we can enjoy the paintings of marine animals by "Madame Davit" (as the illustrator Suzanne Davit was known). He provided the specimens and described the important characteristics for her faithful in water-colour renderings that have always enjoyed pride of place at the IIP, now the Institute of Marine Sciences.

In 1970 he obtained a $\mathrm{PhD}$ and one year later he was promoted to the category of scientific researcher of the CSIC. In the 1980s he began to direct several research projects related to mariculture and fisheries in the bays of the Ebro Delta, oyster cultivation in the Fangar Bay, and natural bivalve banks.

In January 1986 he suffered a great emotional shock when his young assistant, Josep Peitx, in whom he had placed his hopes for continuing the line of bivalve cultivation at the Institute, died in a tragic accident. A year later, the aquarium to which he had dedicated so many years of work and enthusiasm was closed due to a thorough restructuring of the IIP. This was another blow that cast a shadow over the rest of his professional life until he retired in November 1989.

I had the chance to start out in marine biology at his side, when he was 61 years old. Knowing and working with him was a fascinating experience from both a professional and a personal point of view. He conveyed to me his appreciation for aquariology and for the world of bivalves. I will always remember with nostalgia those trips to the Ebro Delta and the Gulf of Valencia to sample oysters, coquina clams and striped venus clams, during which he shared his history with me.

MONTSERRAT RAMÓN

IEO-Centre Oceanogràfic de les Balears

\section{Pere Arté i Gratacós (1924-2009)}

En Pere Arté i Gratacós va néixer a Figueres el 22 de novembre de 1924 i es va llicenciar en Ciències Naturals a Barcelona, l'any 1950. La seva carrera professional es va iniciar com a becari l'any 1949 , abans de llicenciar-se, quan el CSIC va crear la Secció de Biologia Marina i ell va ser un dels assistents al curs Introducción a la Investigación Pesquera, que es va desenvolupar entre Barcelona i Blanes. Ja llavors va manifestar un gran interès pels peixos, publicant aquell mateix any un treball sobre els peixos del litoral de Blanes. Entre els anys 1950 i 1955 va treballar, com a Col-laborador Científic del CSIC, a Vigo. Durant aquest període va col-laborar amb Buenaventura Andreu en estudis sobre el cultiu de l'ostra plana, en un moment en què la situació dels bancs naturals d'aquesta espècie era preocupant. El 1953, Arté i Andreu van visitar els parcs ostrícoles i els laboratoris de la costa atlàntica francesa (Arcachon, Tremblade, Marennnes), adquirint informació que els va resultar de gran utilitat en posteriors estudis sobre fixació de larves, creixement i mortalitat que van dur a terme amb ostres de les ries gallegues.
Aquesta estada a Vigo va ser també molt important des del punt de vista personal, doncs allí hi va conèixer la que seria la seva esposa, Montserrat Escatllar, que treballava com a laborant en el laboratori de Vigo i que, des de llavors, el va acompanyar al llarg de la seva vida.

En tornar de Vigo, Arté va treballar durant dos anys (1956 i 1957) al Laboratori de Blanes de l'Instituto de Investigaciones Pesqueras (IIP) i la primavera de 1958 es va incorporar al Laboratori de Barcelona, quan García del Cid, director de l'IIP, li va encarregar el disseny i construcció del futur Aquari de l'IIP. A partir d'aquest moment, Arté es va dedicar en cos i ànima a aquesta tasca, encarregant-se del seu disseny, de la captació d'aigua, de la decoració dels tancs, i amb l'ajuda de Baldomero Carles i José Grau, els mariners amb qui sortia a "pescar", de poblar l'aquari. També va visitar els aquaris de Mónaco, Lisboa i Porto per intercanviar experiències. Finalment l'aquari, amb una completa mostra de la fauna marina mediterrània, va ser inaugurat el juny de 1963 i la tasca d'Arté va ser reconeguda amb 
la concessió de la Cruz de la Orden de Alfonso X el Sabio. Sota la seva direcció, i amb la col-laboració d'Enric Morales, l'aquari va desenvolupar una important tasca de divulgació del medi marí entre els escolars i el públic general, i va contribuir a la recerca mitjançant diversos treballs d'investigació i Tesis Doctorals, per als quals el manteniment en condicions controlades de peixos i invertebrats era imprescindible.

La tasca d'Arté va ser un bon model de ciència aplicada ja que els seus coneixements científics i tècnics li van permetre elaborar multitud de projectes per resoldre els problemes de captació d'aigües marines als laboratoris costaners i a d'altres aquaris. També va dirigir projectes tècnics de construcció de cetàrees a Barcelona, Tarragona i Mallorca i de vivers per a la cria d'anguiles, va participar en el disseny de depuradores de mol-luscs, etc. Va publicar diversos treballs sobre sistemes d'oxigenació de l'aigua per aquaris, manteniment d'animals en captivitat, llibres d'aquariologia, etc. L'any 1965, juntament amb en F. Lozano i O. Rodriguez, van publicar la Nomenclatura oficial española de los animales marinos de interés pesquero, reeditat al 1972, on van proposar una denominació oficial per unificar les nomenclatures regionals dels peixos, crustacis i mol-luscs comercials. A ell li devem el poder gaudir de les pintures d'animals marins de Madame Davit (tal com ell anomenava la il.lustradora Suzanne Davit), a qui Arté s'encarregava de proporcionar els espècimens i assenyalar-li les característiques rellevants que tant fidelment ella representava en les seves aquarel·les, que sempre han mantingut una posició destacada a l'IIP, avui Institut de Ciències del Mar. Va obtenir el grau de Doctor l'any 1970 i un any més tard ascendí a la categoria d'Investigador Científico del CSIC. A partir dels anys 1980 va dirigir diverses investigacions relacionades amb la maricultura i la pesca a les badies del delta de l'Ebre, el cultiu d'ostra a la badia del Fangar i l'estudi de bancs naturals de bivalves. El gener de 1986 va rebre un fort cop emocional degut a la pèrdua per un tràgic accident del seu jove collaborador, en Josep Peitx, en qui ell havia dipositat les esperances de continuïtat de la línia de cultiu de bivalves a l'Institut. Un any més tard, el tancament i enderrocament de l'Aquari, al qual havia dedicat tants anys de feina i il-lusions, degut a una profunda estructuració de l'IIP, li va tornar a representar moments terriblement amargs que van enterbolir la resta del temps que va treballar fins a la seva jubilació, el novembre de 1989.

Per a mi, que vaig tenir l'oportunitat d'iniciar-me en la biologia marina al seu costat, quan el Dr. Arté ja tenia 61 anys, conèixer-lo i treballar amb ell va ser una experiència fascinant, tant des del punt de vista professional com personal. Ell em va transmetre la seva estimació per l'aquariologia i el món dels bivalves i sempre recordaré, amb nostàlgia, aquells viatges al delta del Ebre i al Golf de València per a mostrejar ostres, tellerines i rossellones, durant els quals em feia partícip de la seva història.

MONTSERRAT RAMÓN IEO-Centre Oceanogràfic de les Balears 